\author{
KatARzyna CuRzyTEK, MARTA KuberA \\ Zakład Neuroendokrynologii Doświadczalnej \\ Instytut Farmakologii im. Jerzego Maja PAN \\ Smętna 12, 31-343 Kraków \\ E-mail: curzytek@if-pan.krakow.pl \\ kubera@if-pan.krakow.pl
}

\title{
ALERGIA KONTAKTOWA - PRZYCZYNA DEPRESJI I BEZSENNOŚCI?
}

\section{KONTAKTOWE ZAPALENIE SKÓRY, DEPRESJA I \\ BEZSENNOSĆ - EPIDEMIOLOGIA I WSPÓŁWYSTĘPOWANIE}

Postępujaca industrializacja i zwiąany $z$ nią rozwój przemysłu chemicznego przyczyniają się do dużej ekspozycji człowieka na różne substancje chemiczne. Moga one zawierać hapteny - substancje o małej masie cząsteczkowej, zdolne do wywoływania nadwrażliwości typu późnego (ang. delayed hypersensitivity, DTH), reakcji układu odpornościowego, która rozwija się w miejscu ekspozycji na hapten i przebiega $z$ udziałem limfocytów T (BLAUVELT i współaut. 2003). Alergiczne kontaktowe zapalenie skóry (ang. allergic contact dermatitis, ACD) jest najczęściej występującym typem DTH u ludzi. Zwierzęcym modelem ACD, który w znaczący sposób przyczynił się do wyjaśnienia mechanizmów leżących u podstaw rozwoju i przebiegu tej choroby, jest reakcja nadwrażliwości kontaktowej (ang. contact hypersensitivity, CHS). ACD występuje u 15-20\% populacji, a zmiany skórne tego typu stanowia około 30\% chorób zawodowych (DIEPGEN i WEISSHAAR 2007, THYSSEN i współaut. 2007). Liczba substancji wywołujacych uczulenie kontaktowe jest bardzo wysoka i wciąż rośnie. Obecnie opisanych jest ponad 3700 takich substancji, które moga być potencjalnymi alergenami kontaktowymi (MARTIN i współaut. 2004). Stale rosnaca liczba pacjentów cierpiących na ACD stanowi coraz poważniejszy problem społeczny i gospodar- czy, wynikający $z$ obniżonej jakości życia i niskiej wydajności pracy.

Choroba afektywna jedno- i dwubiegunowa (potocznie zwana depresja) jest jednym $Z$ najbardziej powszechnych zaburzeń psychicznych i cały czas notuje się wzrost zachorowań. Według WHO (dane $z$ 30.01.2020), ponad 264 milionów ludzi w różnym wieku cierpi $z$ powodu depresji. Główne objawy towarzyszace zaburzeniom depresyjnym obejmują: obniżenie nastroju (smutek, przygnębienie, niska samoocenę, poczucie winy, pesymizm, myśli samobójcze), anhedonię (brak odczuwania przyjemności), a także zaburzenia rytmu dobowego: bezsenność lub nadmierna senność. Zarówno zaburzenia depresyjne, jak i bezsenność, charakteryzują się nie do końca poznana etiologia, ponadto wystapienie objawów obu schorzeń może mieć podłoże genetyczne, wyzwalane pod wpływem przewlekłego stresu i sytuacji życiowych. Zarówno wystąpienie bezsenności, jak i depresji, może być poprzedzone wystapieniem chorób somatycznych, neurologicznych czy przewlekłych zespołów bólowych (HEITZMAN 2009). Pomimo że trudno jednoznacznie stwierdzić, czy bezsenność jest przyczyna czy skutkiem depresji, bezsenność należy do najczęstszych zaburzeń współwystępujacych $z$ depresja, a zaburzenia snu sa przydatnym narzędziem w ocenie ryzyka wystapienia depresji i nawrotów choroby (WICHNIAK i SzMYD 2019). Ponadto, zaburzenia architektury snu [występowanie faz snu: NREM (ang. non-rapid eye movement sleep) i REM (ang. rapid

Słowa kluczowe: alergiczne kontaktowe zapalenie skóry, choroba afektywna jedno- i dwubiegunowa, cytokinowa teoria depresji, leki przeciwdepresyjne, nadwrażliwość kontaktowa

*Praca powstała w wyniku realizacji projektu badawczego o nr 2014/13/N/NZ6/00639 finansowanego ze środków Narodowego Centrum Nauki. 
eye movement), czuwania] i czasu jego trwania, występuja u 90\% pacjentów hospitalizowanych $z$ powodu depresji i 40-60\% pacjentów $z$ depresja, leczonych ambulatoryjnie (HEITZMAN 2009).

Bezsenność, która współwystępuje $z$ inna choroba somatyczna lub psychiczna, nazywamy wtórna, ale bezsenność może być również „autonomiczna” choroba, określana jako bezsenność pierwotna. Stosując kryterium czasu trwania bezsenności, można wyróżnić bezsenność krótkotrwała (zwykle wywołana bodźcem np. bólem lub stresem), bądź bezsenność przewlekłą (mogaca mieć zwiazek $z$ inna choroba, np. depresja). Badania epidemiologiczne (SKALSKI 2014) przeprowadzone na 24600 respondentach wskazuja, że u 27,2\% występowały zaburzenia snu, a najczęściej zgłaszane przez nich problemy dotyczyły trudności $z$ zasypianiem $(10,1 \%)$, trudności $z$ utrzymaniem ciagłości snu (18\%), wczesnego budzenia się (10,9\%, typowego dla depresji) i snu złej jakości, nieprzynoszącego odpoczynku (8,9\%). Choć przyczyny bezsenności wtórnej moga mieć źródło w wielu chorobach, obserwacje i badania kliniczne wskazuja, że bezsenność powiązana $z$ zaburzeniami psychicznymi występuje znacznie częściej niż inne rodzaje bezsenności (SKALSKI 2014).

Biorąc pod uwagę wysoką częstość występowania w populacji ludzkiej, zarówno chorych na alergiczne kontaktowe zapalenie skóry, jak i na depresję (współwystępująca $z$ bezsennością), można przypuszczać, że wystapienie tych chorób jednocześnie jest wysoce prawdopodobne. To współwystępowanie wynika nie tylko $z$ czystego prawdopodobieństwa, ale także $z$ charakteru tych schorzeń. Zwiazek psychiatrii $z$ dermatologia jest dość silny, a ponadto obukierunkowy. Badania ostatnich lat próbują znaleźć odpowiedź na pytanie, jak stan skóry wpływa na stan naszych emocji i odwrotnie, jak emocje (lęk, obniżony nastój, stres, zaburzenia snu) nasilaja objawy schorzeń dermatologicznych. Problem ten jest tak częsty, że możemy mówić o powstaniu nowej dziedziny w medycynie, psychodermatologii. Nie bez znaczenia pozostaje fakt, że nierozerwalny zwiąek skóry i układu nerwowego zaczyna się już w życiu płodowym, gdyż oba narządy rozwijaja się $z$ listka ektodermalnego. Jako największy organ ciała, o powierzchni ok. 2 $\mathrm{m}^{2}$, stanowiacej $15 \%$ całkowitej masy ciała (DĄBROWSKA i współaut. 2018), skóra jest bariera oddzielajaca nas od świata zewnętrznego. Ponadto, skóra jest zarówno składowa układu odpornościowego, jak i metabolicznie aktywnym organem, pełniacym funkcje regulacyjne, wydzielnicze i percepcyjne, przekazującym informacje o bólu, swędzeniu, dotyku czy temperaturze do ośrodkowego układu nerwowego. Jest najbardziej eksponowanym narządem i jej stan może oddziaływać na stan psychiczny. Zwłaszcza w czasach dominacji mediów społecznościowych i ich wpływu na kreację wyidealizowanego wizerunku piekna, osoby $z$ widocznymi dermatozami dotkliwiej moga odczuć odrzucenie, napiętnowanie i brak akceptacji swojego wyglądu zewnętrznego (MAKOWSKA i GMITROWICZ 2014).

Kontaktowe zapalenie dotyczy głównie skóry, najczęściej rąk, co sprawia, że chorzy często sa stygmatyzowani i odrzucani przez społeczeństwo, co w konsekwencji prowadzi do pogorszenia jakości życia i stanu psychicznego. Ocenia się, że objawy $z$ kręgu zaburzeń lękowych i depresyjnych dotycza nawet 30-60\% pacjentów dermatologicznych (GUPTA i GUPTA 2001, MAKOWSKA i GMITROWICZ 2014). Badania przeprowadzone w 13 krajach europejskich (łącznie przebadano 4994 osoby) ujawniły, że występowanie klinicznej depresji u osób cierpiących na schorzenia skóry jest dwukrotnie częstsze niż w grupie osób ze zdrowa skóra (DALGARD i współaut. 2015). Ostatnie badania wykazały, że u europejskich pacjentów $z$ egzema rak, częściej występuja zaburzenia lękowe, depresyjne, myśli samobójcze, w porównaniu $z$ grupa kontrolna (MARRON i współaut. 2018). Wykazano również, że u 1/3 ze 339 pacjentów $z$ alergicznym kontaktowym zapaleniem skóry, które charakteryzuje się przewlekłym bólem i świądem, wystapiły zaburzenia snu (Holness 2001). Polskie badania, przeprowadzone wśród 17 pacjentów z ACD pokazały, że u 5 z nich wystapiły zaburzenia depresyjne (CZARNY-DZIALAK i LATAŁA-ŁOŚ 2014). Co ciekawe, wykazano również, że brak terapeutycznego działania naskórkowej aplikacji kortykosteroidów i doustnego podawania leków przeciwhistaminowych u pacjentów $z$ ACD wywołanym arsenem, był skorelowany $z$ występowaniem objawów depresji u tych pacjentów, zarówno przed, jak i po zastosowaniu wymienionej terapii, w porównaniu do osób odpowiadających na terapię (EL AzIM i współaut. 2009).

\section{UKEAD ODPORNOŚCIOWY - WIODACA ROLA W PRZEBIEGU ACD, DEPRESJI I BEZSENNOSCI}

Reakcja nadwrażliwości kontaktowej jest klasycznym przykładem reakcji układu odpornościowego na miejscowa ekspozycję na niskoczasteczkowe substancje - hapteny, która przebiega $z$ udziałem limfocytów T. Bez względu na rodzaj komórek efektorowych, w odpowiedzi tej można wyróżnić dwa kolejno następujace po sobie eta- 
py: fazę indukcji i fazę efektorowa (KIMBER i DEARMAN 2002). CHS jest złożonym procesem, w przebieg którego zaangażowanych jest wiele rodzajów komórek, między innymi: keratynocyty, komórki prezentujace antygen (ang. antigen-presenting cells, APC), komórki śródbłonka, mastocyty, antygenowo swoiste limfocyty B1, limfocyty NKT (ang. natural killer T-cells), dwa różne typy limfocytów $\mathrm{T}$ efektorowych (Th1 CD4 ${ }^{+}$lub Tc1 $\mathrm{CD}^{+}$) oraz leukocyty krwi obwodowej (monocyty i neutrofile) (MAJEWSKA i SzCZEPANIK 2009). Na przestrzeni lat przebieg reakcji w jej poszczególnych fazach został dość szczegółowo poznany dzięki doświadczeniom przeprowadzonych na różnych szczepach myszy. W fazie indukcji, przy pierwszym kontakcie $z$ haptenem, penetruje on do naskórka, gdzie, łącząc się białkami, tworzy tzw. neoantygeny, które mogą być rozpoznane przez rezydujace tam komórki dendrytyczne (głównie komórki Langerhansa, LC). Aktywowane komórki LC wydzielają duże ilości interleukiny(IL)-1 $\beta$, która pobudza keratynocyty do wydzielania m.in. czynnika martwicy nowotworu (ang. tumor necrosis factor, TNF)-a oraz czynnika stymulujacego tworzenie kolonii granulocytów i makrofagów (ang. granulocyte-macrophage colony-stimulating factor, GM-CSF), a te współdziałajac $z$ IL-1 $\beta$, wpływaja na obniżenie ekspresji E-kadheryny na komórkach LC. Powoduje to rozluźnienie i rozerwanie połaczeń komórek $\mathrm{LC} z$ keratynocytami oraz pozwala na dalsza ich migrację przez naskórek do lokalnych węzłów chłonnych. Komórki dendrytyczne, które dotarły do węzłów chłonnych, przetwarzaja i prezentuja antygen naiwnym limfocytom T. Antygeny sa prezentowane limfocytom T $\mathrm{CD}^{+} \mathrm{w}$ kontekście antygenów zgodności tkankowej klasy I (ang. major histocompatibility complex, MHC) lub limfocytom T CD4 ${ }^{+}$ w kontekście MHC klasy II (SAINT-MEZARD i współaut. 2004). Jednocześnie $z$ wędrówka komórek LC do węzłów chłonnych zaobserwowano, że już kilka minut po ekspozycji na hapten, następuje aktywacja komórek NKT w wątrobie, które uwalniają IL-4, co pobudza limfocyty B do syntezy przeciwciał IgM, swoistych względem haptenu (ASKENASE i współaut. 2011). Następnie aktywowane limfocyty $\mathrm{T}$ proliferują i różnicują się w komórki pamięci oraz komórki efektorowe o fenotypie $\mathrm{TCRa}^{+} \mathrm{CD}^{+}$(Tc1) bąd́ $\mathrm{TCRa} \beta^{+} \mathrm{CD}^{+}$ (Th1) późnej fazy reakcji CHS. Komórki efektorowe pojawiaja się w ciagu 3-4 dni od immunizacji haptenem. Tak zaktywowane limfocyty $\mathrm{T}$ efektorowe trafiaja do krwiobiegu i moga w nim krążyć latami, jako komórki pamięci lub trafić szybko do miejsca zapalenia. Po ponownym kontakcie $z$ haptenem (przy czym miejsce ponownego wniknięcia haptenu może być inne niż miejsce ekspozycji w fazie indukcji), następuje faza efektorowa reakcji CHS. Można w niej wyodrębnić 2 etapy wyzwalania reakcji CHS: wczesny (zwiazany $z$ aktywacja przeciwciał IgM; minuty po ponownej ekspozycji na hapten) i późny (związany $z$ aktywacją efektorowych limfocytów T; rozwija się po około $24 \operatorname{godz}$. od ponownej aplikacji haptenu) (MAJEWSKA i SzCZEPANIK 2009). Przeciwciała IgM aktywuja układ dopełniacza, który wpływa na lokalne uwolnienie takich czynników jak: serotonina, cytokiny (TNF-a, GM-CSF), chemokiny, leukotrieny i prostaglandyny (TSUJI i współaut. 1996), co w komórkach śródbłonka indukuje ekspresję cząsteczek adhezyjnych ICAM-1 i VCAM-1, ułatwiajaca toczenie się, przyleganie i przechodzenie komórek efektorowych $\mathrm{T}$ do miejsca zapalenia. $Z$ kolei napływ efektorowych limfocytów T, wiąże się $z$ uwalnianiem licznych mediatorów reakcji zapalnej, m.in.: IL-2, IL-4, IL-5, IL-6, IL-10, IL-13, IL-17A, IL-17F, IL-21, IL-22, IL-26, IFN- $\gamma$, TNF-a i GM-CSF (HUS i współaut. 2010, SILVESTRE i współaut. 2018). Kluczową rolę w odpowiedzi na hapten pełnia również licznie występujace w skórze keratynocyty, które, pod wpływem toczacej się reakcji zapalnej, stają się źródłem licznych czynników chemotaktycznych takich jak: IL-1 $\beta$, TNF-a, CXCL1 (KC), CXCL2 (MIP-2a), CXCL9 (MIG), CXCL10 (IP-10), CCL2 (MCP-1), CCL5 (RANTES), CCL8 (MCP-2), CCL17 (TARC), CCL22 (MDC) i CCL27 (FLIER i współaut. 2001, KARSAK i współaut. 2007, MORI i współaut. 2008, HoNDA i współaut. 2013). Uwolnione czynniki powoduja wzmożony napływ neutrofili, komórek dendrytycznych i monocytów, które przekształcaja się w makrofagi, co prowadzi do eskalacji odpowiedzi zapalnej. W miejscu reakcji na skórze pojawia się zaczerwienienie i obrzęk, a po osiagnięciu szczytu po 24/48 godz. od powstania, zapalenie zaczyna powoli ustępować dzięki aktywnym mechanizmom regulacyjnym, które ograniczaja uszkodzenia tkanek i utrzymuja integralność skóry. Regulacja reakcji CHS jest zależna od wielu czynników i komórek, ale wiodąca rolę pełnia limfocyty $\mathrm{T}$ regulatorowe o różnych fenotypach: $\mathrm{CD}^{+} \mathrm{CD} 25^{+} \mathrm{Foxp}^{+}$, limfocyty Treg typu 1 (Tr1) i limfocyty Th3 oraz IL10, uwalniana m.in. przez limfocyty Treg i komórki dendrytyczne (Martins i ReIS 2011, Silvestre i współaut. 2018).

Liczne badania, zapoczatkowane w latach 90. XX w. dowiodły, że u podłoża zaburzeń depresyjnych leży aktywacja prozapalnej komponenty układu odpornościowego (MAES i współaut. 1991, SMITH 1991). U osób chorych na depresje stwierdzono wzrost liczby leukocytów i neutrofili, wzrost liczby limfocytów $\mathrm{T} \mathrm{CD}^{+} \mathrm{i}$ produkowanego przez nie 
rozpuszczalnego receptora dla IL-2 (sIL-2), spadek liczby limfocytów $\mathrm{T}$ supresyjnych $\mathrm{i}$ cytotoksycznych T $\mathrm{CD}^{+}$(MAES i współaut. 1991, 1992; KUBERA i współaut. 1999; LIU i współaut. 2012). Ponadto, chorzy na depresję przejawiaja podwyższony poziom bialek ostrej fazy w surowicy. U chorych obserwuje się wzrost poziomu haptoglobiny, a1-antytrypsyny, cerulopazminy czy białka C-reaktywnego (SWARTZ 1990, SLUZEWSKA 1996, FAUGERE i współaut. 2018). Istotne znaczenie dla powstania koncepcji zapalnego podłoża depresji ma opublikowana przez SMITHA w 1991 r. praca, mówiąca o "makrofagowej” lub „cytokinowej” teorii depresji. Teoria ta zakłada, że przyczyna depresji jest nadmierne wydzielanie cytokin prozapalnych [interleukina (IL)- 1 , interferon (IFN)- $\gamma$ i czynnik martwicy nowotworu (TNF)-a], oddziałujacych na obwodowy/centralny system nerwowy poprzez zaburzanie homeostazy układu neuroendokrynnego. To skutkuje aktywacja osi HPA (ang. hypothalamic-pituitary-adrenal; oś podwzgórze-przysadka-nadnercza) i eliminacji tryptofanu - prekursora serotoniny, w wyniku aktywacji 2,3-dioksygenazy indolowej (ang. indoleamine 2,3-dioxygenase, IDO), enzymu przekształcajaccego tryptofan w kynureninę.

Kolejne badania nie tylko potwierdzily, ale i uzupełniły cytokinowa teorię depresji. Aktywacja układu odpornościowego ma miejsce $\mathrm{w}$ przebiegu depresji, choć należy podkreślić, że nie dotyczy to wszystkich pacjentów chorujących na depresję. Obecnie uważa się, że za rozwój depresji odpowiedzialna jest nie tylko aktywacja układu odpornościowego, ale również procesy stresu oksydacyjnego/nitrozacyjnego oraz indukcja, badź podtrzymywanie stanem zapalnym zmian neurodegeneracyjnych (MAES i współaut. 2009). Znacząca role w patogenezie depresji przypisuje się również zaburzeniom $\mathrm{w}$ interakcji pomiędzy neuronami i mikroglejem (ŚLUSARCZYK i współaut. 2018), a także mikroflorze jelitowej, której skład odgrywa bar$\mathrm{dzo}$ istotna rolę $\mathrm{w}$ prawidłowym funkcjonowaniu mózgu (HORNE i FOSTER 2018).

Badania naukowe prowadzone na przestrzeni lat dowiodły, że sen jest procesem regulowanym zarówno przez fizjogiczna potrzebę regeneracji (potrzeba behawioralna), jak i przez molekularny zegar biologiczny, $z$ nadrzędną funkcja jądra nadskrzyżowaniowego (ang. suprachiasmatic nucleus, SCN). Ponadto, sen może być regulowany przez czynniki zewnętrzne, jak światło, temperatura, stres, używki, oraz poprzez czynniki wewnętrzne, do których należą: hormony, neuropeptydy, prostaglandyny czy cytokiny (CICHON i CHADZINSKA 2013). Jeśli przyjrzymy się bliżej czynnikom wewnętrznym odpow- iedzialnym za regulację snu to zauważymy, że wiele $z$ nich jest zaangażowanych także w przebieg depresji i uczulenia kontaktowego. Do hormonów regulujących sen zaliczamy melatoninę, kortyzol, hormon adrenokortykotrpowy (ang. adrenocorticotrophic hormone, ACTH), kortykoliberynę (ang. corticotropin-releasing hormone, CRH), hormon wzrostu (ang. growth, GH), prolaktynę czy wazopresynę, wśród neuropeptydów odnajdziemy m.in. neuropeptyd $\mathrm{Y}$ i serotoninę, a najlepiej poznane cytokiny regulujące sen to: IL-1 $\beta$, TNF-a i IL-6 (CICHON i CHADZINSKA 2013). Wiadomo, że IL-1 $\beta$ i TNF-a sa zaangażowane $\mathrm{w}$ fizjologiczną regulację snu; podanie egzogenne obu cytokin indukuje wzmożony sen fazy NREM, a ich blokowanie redukuje długość snu. Ponadto, podwyższony poziom TNF-a obserwowano $u$ pacjentów cierpiacych na chroniczne zmęczenie i przewlekłą bezsenność oraz u osób poddanych deprywacji snu (DAVIS i KRUEGER 2012). Natomiast IL-6 jest wydzielana głównie w czasie snu, a spadek jej syntezy obserwuje się w ciagu dnia (CichON i CHADZINSKA 2013). Metaanaliza 72 prac badawczych (N $>50$ 000) ujawniła, że zaburzenia snu sa skorelowane $z$ wyższym poziomem IL- 6 i białka CRP w surowicy badanych pacjentów (BLAKE i współaut. 2018). IL-6 podnosi również wydzielanie takich hormonów jak: ACTH czy kortyzol, które $z$ kolei wpływaja na blokowanie syntezy, działajacej nasennie IL-2. Wiadomo również, że utrzymujące się zaburzenia snu prowadza do przewlekłego stanu zapalnego, a ten $z$ kolei obserwujemy $\mathrm{w}$ przebiegu zarówno depresji, jak i uczuleniu kontaktowym. Odwrotnie, przewlekły stan zapalny (w depresji, jak i uczuleniu kontaktowym - schorzeniach przewlekłych i nawracających) staje się przyczyna zaburzeń snu. Co ciekawe, działajaca przeciwzapalnie IL-10, hamujacc cytokiny prozapalne, wpływa na redukcję snu. Być może ma to zwiazek $z$ tym, że podczas snu, następuje przesunięcie odporności typu komórkowego na korzyść limfocytów Th1, ze zwiększona produkcja IFN- $\gamma$ i zmniejszona IL-10, przez co wydłużenie snu, np. w trakcie trwania infekcji, zwiększa prawdopodobieństwo szybszego wyzdrowienia (IRWIN 2019). W świetle powyższych dniesień zaskakującym jest to, że krótkotrwała deprywacja snu może mieć działanie przeciwdepresyjne (SikKens i współaut. 2019).

\section{LEKI PRZECIWDEPRESYJNE - STOSOWANIE W LECZENIU ACD I BEZSENNOŚCI}

W badaniach przeprowadzonych na myszach $z$ indukowana reakcja CHS dowie- 
dziono, że leki przeciwdepresyjne, takie jak fluoksetyna i dezypramina, hamuja $z$ bardzo wysoka, około 50\% skutecznościa, reakcję nadwrażliwości kontaktowej na hapteny, niezależnie od tego, jaki rodzaj limfocytów efektorowych $\mathrm{T}\left(\mathrm{CD}^{+}{ }^{+} \mathrm{czy} \mathrm{CD}^{+}\right)$przeważał w fazie efektorowej reakcji (KUBERA i współaut. 2012, CurzyTeK i współaut. 2013). Ponadto, badania przeprowadzone $z$ udziałem myszy knock-out wykazały, że inhibicyjne działanie leków przeciwdepresyjnych (LPD) na przebieg reakcji CHS wiąże się $z$ ich oddziaływaniem na populację limfocytów $\mathrm{T} \mathrm{CD}^{+} \mathrm{i}$ NKT, pozostajacc bez wpływu na limfocyty

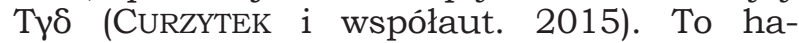
mujace działanie fluoksetyny i dezypraminy na przebieg reakcji CHS wiązało się również $z$ ich wpływem na szereg parametrów odpowiedzi immunologicznej. LPD hamowały podwyższoną CHS, spontaniczna i stymulowana mitogenem, aktywność proliferacyjna (mierzona testem inkorporacji $\left[{ }^{3} \mathrm{H}\right]$-tymidyny) i/lub aktywność metaboliczna (mierzona testem MTT) komórek izolowanych ze śledzion i węzłów chłonnych badanych zwierząt. LPD powodowały również obniżenie masy takich narząów limfatycznych jak: węzły chłonne pachowe i pachwinowe, grasica i śledziona, podwyższonej w wyniku aplikacji haptenu. Ponadto, dezypramina i fluoksetyna hamowały wydzielanie (przez stymulowane mitogenem komórki śledziony i/lub węzłów chłonnych) cytokin o potencjale prozapalnym (IL-4, IL-6 i IFN-ү) i zwiększały wydzielanie przeciwzapalnej IL-10 (KUBERA i współaut. 2012; CURZYTEK i współaut. 2013, 2015). Ponadto, w modelu in vitro reakcji $\mathrm{CHS}, \mathrm{z}$ wykorzystaniem linii komórkowych ludzkich keratynocytów HaCaT i mysich prekursorów komórek dendrytycznych JAWSII, również obserwowano inhibicyjne działanie LPD na syntezę czynników prozapalnych (dane w trakcie publikacji). Obecność LPD w stymulowanych hodowlach obu linii komórkowych wpływała na hamowanie takich mediatorów zapalenia jak: IL-1 $\beta$, IL-6, CCL2 (MCP-1), XCL1 i CXCL5. Ponadto, zastosowane LPD obniżały ekspresję czasteczek adhezyjnych ICAM-1 (ang. intercellular adhesion molecule 1) i zwiększały ekspresje E-kadheryny w hodowlach keratynocytów HaCaT.

Leki przeciwdepresyjne sa także stosowane w leczeniu bezsenności. Tradycyjnie, farmakologia bezsenności jest zwiazana $z$ receptorem GABA (kwas $\mathrm{\gamma}$-aminomasłowy). W przeszłości w leczeniu bezsenności używano etanolu i barbituranów, obecnie stosuje się agonistów receptorów benzodiazepinowych (BZD), czyli benzodiazepiny oraz leki nasenne nowej generacji: zolpidem, zopiklon i zaleplon (SKALSKI 2014). Aktualne wytyczne terapeutyczne zdecydowanie zalecaja stosowanie te- rapii poznawczo-behawioralnej, jako początkowego leczenia przewlekłej bezsenności, i tylko krótkotrwałe stosowanie leków nasennych u pacjentów $z$ niewystarczająca odpowiedzia na terapię behawioralna (WICHNIAK i współaut. 2017). Jednak w praktyce klinicznej użycie farmakoterapii w leczeniu bezsenności jest powszechne i jeśli wymaga przewlekłego stosowania, alternatywa dla wyżej wymienionych leków nasennych, staja się leki przeciwdepresyjne. Najczęściej stosuje się leki przeciwdepresyjne o profilu uspokajającym, takie jak trazodon, mianserynę, mirtazapinę, doksepinę i opipramol (SKALSKI 2014, WICHNIAK i współaut. 2017). Co ciekawe, z powyższych, tylko doksepina została oficjalnie zarejestrowana w leczeniu bezsenności przez FDA. Ponadto doksepina, należąca do trójcyklicznych leków przeciwdepresyjnych, znalazła swoje zastosowanie również $\mathrm{w}$ leczeniu atopowego zapalenia skóry. Nasze badania poświęcone mechanizmowi hamowania nadwrażliwości kontaktowej przez leki przeciwdepresyjne, również wskazuja na ich korzystne działanie w kontekście leczenia bezsenności. Wydaje się, że ich działanie sedatywne może być zwiazane nie tylko $z$ ich bezpośrednim oddziaływaniem na poziom neurotransmiterów, ale również $z$ ich właściwościami immunomodulacyjnymi. Udowodniliśmy, że hamujacc CHS, leki przeciwdepresyjne hamuja wydzielanie takich cytokin jak IL-1 $\beta$ czy IFN- $\gamma$, bezpośrednio zaangażowanych w zaburzenia snu. Leki przeciwdepresyjne hamowały również wydzielanie przez keratynocyty i komórki dendrytyczne chemokiny CCL2, której wzmożone wydzielanie w przebiegu CHS jest w dużej mierze odpowiedzialne za odczuwanie bólu i świądu, co również może wpływać na zaburzenia snu u chorych na ACD (JIANG i współaut. 2019). Takie właściwości obserwowaliśmy używając w badaniach zarówno leki trójcykliczne, jak imipramina i dezypramina, ale także lek $z$ grupy SSRI (inhibitor wychwytu zwrotnego serotoniny), fluoksetynę. Chociaż fluoksetyna niewatpliwie może działać na komponentę prozapalna, to $\mathrm{w}$ praktyce klinicznej stosowanie leków przeciwdepresyjnych $z$ grupy SSRI może wzmagać bezsenność, więc w leczeniu tego schorzenia bardziej przydatne sa trójcykliczne leki przeciwdepresyjne. Mówiąc o lekach przeciwdepresyjnych, które wpływaja na sen, nie można zapomnieć o agomelatynie, leku, który swoje przeciwdepresyjne działanie zawdzięcza normalizacji zaburzonego rytmu snu i czuwania (WICHNIAK i SzMYD 2019).

\section{PODSUMOWANIE}

Chorobom dermatologicznym często towarzysza zaburzenia $z$ kręgu depresji i bezsenności. Wynika to zarówno $z$ zapalnego 
charakteru wielu chorób skóry, jak i z obciażenia psychicznego spowodowanego zmianami widocznymi na skórze. Dlatego choroby skóry, w tym alergiczne kontaktowe zapalenie skóry, moga być czynnikiem ryzyka dla wystapienia depresji i bezsenności. Wydaje się, że stosowanie leków przeciwdepresyjnych w niskich dawkach, których używa się w praktyce klinicznej w leczeniu bezsenności, może być jeszcze bardziej uzasadnione w przypadku chorych na alergiczne kontaktowe zapalenie skóry. Ich przeciwzapalne właściwości moga przyczyniać się do wywołania korzystnych efektów przeciwuczuleniowych, przeciwdepresyjnych i poprawiajacych jakość snu, a przez to znaczaco poprawiać jakość życia pacjentów $z$ chorobami skóry.

\section{Streszczenie}

Nowoczesny styl życia, zanieczyszczenia środowiska i postepujaca industrializacja przyczyniaja sie do wzrostu zachorowań na alergiczne kontaktowe zapalenie skóry, które jest reakcja odpornościowa na niskoczasteczkowe substancje - hapteny. Klinicznie manifestuje się na skórze obrzękiem, pecherzami i pęknięciami, którym dodatkowo towarzyszy ból i świąd. Zapalny charakter choroby i widoczne na skórze zmiany przyczyniaja się do pogorszenia jakości życia chorych oraz zwiększaja prawdopodobieństwo wystapienia zaburzeń depresyjnych. Niewatpliwie objawy $z$ kręgu zaburzeń lękowych i depresyjnych (przebiegajacych $z$ bezsennością) moga dotyczyć nawet $60 \%$ pacjentów dermatologicznych. Ponadto, jakość snu oraz stan skóry sa ze sobą ściśle skorelowane i wzajemnie na siebie oddziałuja. Niezwykle obiecujace sa wyniki badań ostatnich lat, które wskazują, że leki przeciwdepresyjne, w praktyce klinicznej stosowane w leczeniu bezsenności, hamują również reakcję nadwrażliwości kontaktowej. Dlatego niniejsza praca jest poświęcona problemowi współwystępowania chorób skóry, depresji i bezsenności, roli układu odpornościowego w etiologii tych chorób oraz immunomodulacyjnych właściwości leków przeciwdepresyjnych, mogących wywierać terapeutyczne efekty w chorobach $z$ zakresu psychodermatologii.

\section{LITERATURA}

Askenase P. W., MAJEWSKa-SzCZEPaniK M., KeRFOOT S., SzCZEPANIK M., 2011. Participation of inkt cells in the early and late components of Tc1-mediated DNFB contact sensitivity: cooperative role of $\gamma \delta$ - $T$ cells. Scand. J. Immunol. $73,465-477$

BlaKe M. J, TRINDER J. A., Allen N., 2018. Mechanisms underlying the association between insomnia, anxiety, and depression in adolescence: implications for behavioral sleep interventions. Clin. Psychol. Rev. 63, 25-40.

Blauvelt A., Hwang S. T., Udey M. C., 2003. Allergic and immunologic diseases of the skin. J. Allergy Clin. Immunol. 111, 560-570.

CichON I., ChADZINSKA M., 2013. Czy Układ Odpornościowy Reguluje Nasz Sen? Wszechświat $114,44-49$

CURZYTEK K., KUBERA M., MAJEWSKA-SZCZEPANIK M., SZCZEPANIK M., MARCIŃSKA K., PTAK W., Duda W., LEŚKIEWICZ M., BASTA-KAIM A., BudziszewsKa B., Lasoñ W., Maes M., 2013. Inhibition of 2,4-dinitrofluorobenzene-induced contact hypersensitivity reaction by antidepressant drugs. Pharmacol. Rep. 65, 1237-1246.

CURZYTEK K., KUBERA M., MAJEWSKA-SZCZEPANIK M., SZCZEPANIK M., PTAK W., DUDA W., LEŚKIEWICZ M., BASTA-KAIM A., BUDZISZEWSKA B., Regulska M., KoRZENiAK B., GEOMBIK K., MAES M., LASON W., 2015. Inhibitory effect of antidepressant drugs on contact hypersensitivity reaction is connected with their suppressive effect on NKT and CD8+T Cells but not on TCR delta $T$ cells. Int. Immunopharmacol. 28, 1091-1096.

CZARNY-DZIAEAK M., LATAEA-ŁoŚ E., 2014. Evaluation of the impact of severity of itching symptoms on the level of depression in patients with allergic contact eczema (preliminary study). Med. Studies 2, 106-110.

Dąrowska A. K., SPANO F., DERlER S., ADLHART C., SPEncER N. D., Rossi M. R., 2018. The relationship between skin function, barrier properties, and body-dependent factors. Skin Res. Technol. 24, 165-174.

DAlgard F. J., Gieler U., TOMAS-ARAgones L., Lien L., PoOt F., Jemec G. B. E., Misery L., SZABO C., Linder D., SAMPOGNA F., Evers A. W. M., Halvorsen J. A., Balieva F., SZEPIETOWSKI J., ROMANOV D., MARRON S. E., ALTUNAY I. K., FINLAY A. Y., SALEK S. S., KUPFER J., 2015. The psychological burden of skin diseases: a cross-sectional multicenter study among dermatological out-patients in $13 \mathrm{Eu}$ ropean countries. J. Investig. Dermatol. 135, 984-991.

Davis C. J., KRUEger J. M., 2012. Sleep and cytokines. Sleep Med. Clin. 7, 517-527.

DIEPGEN T. L., WEISSHAAR E., 2007. Contact dermatitis: epidemiology and frequent sensitizers to cosmetics. J. Eur. Acad. Dermatol. Venereol. 21 (Suppl. 2), 9-13.

El AzIM S. A., SElim A. A., El-Raheem T. A., 2009. The Influence of Depression on the Outcome of Treatment in Occupational Dermatoses Workers. J. Dermatol. Treat. 20, 203-207.

Faugere M., Micoulaud-Franchi J. A., FAGET-AgiUS C., LANCON C., CERMOlaCCE M., RICHIERI R., 2018. High c-reactive protein levels are associated with depressive symptoms in schizophrenia. J. Affect. Disord. 225, 671-675.

Flier J., BOORSMA D. M., VAN BEEK P. J., NIEBOeR C., Stoof T. J., Willemze R., TEnSEN C. P., 2001. Differential expression of CXCR3 targeting chemokines CXCL10, CXCL9, and CXCL11 in different types of skin inflammation. J. Pathol. 194, 398-405.

GuPTA M. A, GUPTA A. K., 2001. The Use of Antidepressant Drugs in Dermatology. J. Eur. Acad. Dermatol. Venereol. 15, 512-518.

HEITZMAN J., 2009. Sleep disturbances-cause or result of depression. Psychiatria Polska 43, 499-511.

HOLNESS D. L., 2001. Results of a quality of life questionnaire in a patch test clinic population. Contact Dermat. 44, 80-84.

Honda T., EgawA G., GrabBE S., Kabashima K. 2013. Update of immune events in the murine contact hypersensitivity model: toward the understanding of allergic contact dermatitis. J. Invest. Dermatol. 133, 303-315.

HORNE R., FOSTER J. A., 2018. Metabolic and microbiota measures as peripheral biomarkers in major depressive disorder. Fron. Psychiatry 9, 513 .

Hus I., MaciąG E., Roliński J., 2010. The role of Th17 cells in anti-cancer immunity. Post. Hig. Med. Dośw. 64, 244-250. 
IRWIN M. R., 2019. Sleep and inflammation: partners in sickness and in health. Nat. Rev. Immunol. 19, 702-715.

Jiang H., Cui H., Wang T., Shimada S.G., Sun R., TAN Z., MA C., LAMOTTE R. H., 2019. CCL2/ CCR2 signaling elicits itch- and pain-like behavior in a murine model of allergic contact dermatitis. Brain Behav. Immun. 80, 464473.

KaRsaK M., Gaffal E., DATE R., WANG-EcKHARDT L., Rehnelt J., Petrosino S., Starowicz K., Steuder R., Schlicker E., CRAvatT B., Mechoulam R., BuetTNeR R., Werner S., DI MARZO V., TÜTING T., ZIMMER A., 2007. Attenuation of allergic contact dermatitis through the endocannabinoid system. Science 316, 1494-1497.

KIMBER I., DEARMAN R. J., 2002. Allergic contact dermatitis: the cellular effectors'. Contact Dermat. 46, 1-5.

Kubera M., VAN Bockstaele D., Maes M., 1999. Leukocyte subsets in treatment-resistant major depression. Pol. J. Pharmacol. 51, 547-549.

KUBERA M., CURZYTEK K., MAJEWSKA-SZCZEPANIK M., SZCZEPANIK M., MARCIŃSKA K., PTAK W., LEŚKIEWICZ M., MAes M., BASTA-KaIM A., BUDZISZEWSKA B., DETKA J., DUDA W., LASON W., 2012. Inhibitory effect of antidepressant drugs on contact hypersensitivity reaction. Pharmacol. Rep. 64, 714-722.

LIU Y., CHUN MAN HO R., MAK A., 2012. Interleukin (IL)-6, tumour necrosis factor alpha (TNF-a) and soluble interleukin-2 receptors (SIL-2R) are elevated in patients with major depressive disorder: a meta-analysis and meta-regression. J. Affec. Disord. 139, 230-239.

Maes M., Bosmans E., Suy E., Vandervorst C. DEJONCKHEERE C., RAUS J., 1991. Depression-related disturbances in mitogen-induced lymphocyte responses and interleukin-1 $\beta$ and soluble interleukin-2 receptor production. Acta Psychiatr. Scand. 84, 379-386.

Maes M., Stevens W., DeClerCK L., Bridts C., Peeters D., SchotTe C, Cosyns P., 1992. Immune Disorders in Depression: Higher $T$ Helper/T Suppressor-Cytotoxic Cell Ratio. Acta Psychiatr. Scand. 86, 423-431.

MAeS M., YiRmyia R., NORABERG J., BREne S., HibBeln J., Perini G., Kubera M., BOB P., LERER B., MAJ M., 2009. The Inflammatory \& Neurodegenerative (I\&ND) hypothesis of depression: leads for future research and new drug developments in depression. Metab. Brain Disease 24, 27-53.

MAJEWSKA M., SZCZEPANIK M., 2009. Reakcja nadwrażliwości kontaktowej, jej mechanizm i regulacja. Post. Hig. Med. Dośw. 63, 47-57.

MAKOWSKA I., GMITROWICZ A., 2014. Psychodermatologia - pogranicze dermatologii, psychiatrii $i$ psychologii. Psychiatria i Psychologia Kliniczna. 14, 100-105.

MARRON S. E., TOMAS-ARAgONES L., NAVARRO-LOPEZ J., GIEleR U., KUPfER J., DALGARD F. J., LiEN L., Finlay A. Y., POOT F., LiNDER D., SzePietowski J. C., Misery L., JeMEC G. B. E., ROMANOV D., SAMPOGNA F., SZABO C., ALtUNAY I. K., SPILlEKOM-VAN Koulil S., BalieVA F., Ali F. M., Halvorsen J. A., MariJuan P. C., 2018. The psychosocial burden of hand eczema: data from a European dermatological multicentre study. Contact Dermat. 78, 406412
Martin S. F., DudDa J. C., DelatTRE V., BACHTANIAN E., LEICHT C., BURGER B., WELTZIEN H. U., Simon J. C., 2004. Fas-mediated inhibition of $C D 4+T$ cell priming results in dominance of type $1 \mathrm{CD} 8+T$ cells in the immune response to the contact sensitizer trinitrophenyl. J. Immunol. 173, 3178-3185.

Martins L. E. A. M., Silva dos Reis V. M., 2011. Imunopatologia da dermatite de contato alérgica. Anais Brasileiros de Dermatologia 86, 419-433.

MORI T., KABASHIMA K., YOSHIKI R., SUGITA K., SHIRAISHI N., ONOUE A., KURODA E., KOBAYASHI M., YAMASHITA U., TOKURA Y., 2008. Cutaneous hypersensitivities to hapten are controlled by IFN-Y-upregulated keratinocyte Th1 chemokines and IFN- $Y^{-}$downregulated Langerhans cell Th2 chemokines. J. Invest. Dermatol. 128, 1719-1727.

SAinT-MEzarD P., KRASTEVA M., Berard F., DuBOIS B., KAISERLIAN D., NICOlAS J. F., 2004. Allergic Contact Dermatitis. Skin Immune System 14, 593-613.

Sikkens D., Riemersma-VAn DeR LeK R. F., MeESTERS Y., SCHOEVERS R. A., HAARMAN B. C. M., 2019. Combined sleep deprivation and light therapy: clinical treatment outcomes in patients with complex unipolar and bipolar depression. J. Affect. Disord. 246, 727-730.

Silvestre M. C., Silva dos Reis V. M., SATO M. N., 2018. Innate Immunity and Effector and Regulatory Mechanisms Involved in Allergic Contact Dermatitis. Anais Brasileiros de Dermatologia. 93, 242-250.

SKALSKI M., 2014. Bezsenność - patogeneza $i$ leczenie. Kosmos 63, 233-243.

SLUZEWSKA A., 1996. Concentration and microheterogeneity glycophorms of alpha-1-acid glycoprotein in major depressive disorder. J. Affec. Disord. 39, 149-155.

SMITH R. S., 1991. The macrophage theory of depression. Med. Hypothes. 35, 298-306.

SWARTZ C. M., 1990. Albumin decrement in depression and cholesterol decrement in mania. J. Affec. Disord. 19, 173-176.

ŚlusarczyK J., Trojan E., GŁombik K., PiotrowSKA A., BUDZISZEWSKA B., KUBERA M., POPIOŁEK-BARCZYK K., LASON W., MIKA J., BASTA-KAIM A., 2018. Targeting the NLRP3 inflammasome-related pathways via tianeptine treatment-suppressed microglia polarization to the M1 phenotype in lipopolysaccharide-stimulated cultures. Int. J. Mol. Sci. 19, 1-23.

Thyssen J. P., Linneberg A., Menné T., Johansen J. D., 2007. The epidemiology of contact allergy in the general population-prevalence and main findings. Contact Dermatit. 57, 287299.

TSUJI R. F., KikUChI M., Askenase P. W., 1996. Possible involvement of $\mathrm{C5} / \mathrm{C} 5 \mathrm{a}$ in the efferent and elicitation phases of contact sensitivity. J. Immunol. 156, 4644-4650.

WICHNIAK A., SZMYD J., 2019. Treatment of depression through normalisation of sleep-wake rhythm disorders. Psychiatria i Psychologia Kliniczna. 19, 338-343.

WICHNIAK A., WIERZBICKA A., WALECKA M., JERNAJCZYK W., 2017. Effects of Antidepressants on sleep. Curr. Psychiatry Rep. 19, 1-7. 
KOSMOS Vol. 69, 3, 475-482, 2020

\section{Katarzyna Curzytek, Marta Kubera}

Department of Experimental Neuroendocrinology, Maj Institute of Pharmacology PAS, 12 Smętna Str., 31-343 Kraków, E-mail: curzytek@if-pan.krakow.pl, kubera@if-pan.krakow.pl

ALLERGIC CONTACT DERMATITIS - THE CAUSE OF DEPRESSION AND INSOMNIA?

\section{Summary}

Modern lifestyle, environmental pollution and the progressive industrialization contribute to increased incidence of allergic contact dermatitis, which is an immune reaction to the low molecular weight substances - haptens. Clinically, it manifests as the skin swelling, blisters and cracks, also accompanied by pain and itching. The inflammatory nature of the disease and visible changes on the skin contribute to the deterioration of the quality of life of patients and increase the likelihood of depressive disorders' occurrence. Undoubtedly, the symptoms of the anxiety, depressive disorders, insomnia can affect up to $60 \%$ of dermatological patients. Besides, quality of sleep and skin condition are closely correlated and interact with each other. Extremely promising are the results of recent years, which show that antidepressants, used in clinical practice for the treatment of insomnia, also inhibit contact hypersensitivity reaction. Therefore, this work is dedicated to the coexistence of skin diseases, depression, and insomnia, the role of the immune system in the etiology of these diseases and the immunomodulatory properties of antidepressant drugs, which may have therapeutic effects on psychodermatological diseases.

Key words: allergic contact dermatitis, anti-depressive drugs, contact hypersensitivity, depression, cytokine theory of depression 